\title{
Investigating the Antecedents of Purchase Intention Toward Local Dairy Products: An Empirical Study Based on the SOR Model
}

\author{
Nadjim Mkedder ${ }^{1}$, Mahmut Bakir², Abdelheq Lachachi
}

Submitted: 28.01.2021. Accepted: 13.04.2021

\section{Abstract}

Purpose: The aim of this study was to investigate the antecedents of consumers' purchase intention toward local dairy products. In doing so, this article delves into the relationships between perceived quality, perceived price, customer satisfaction, brand image, and customer purchase intention in the context of developing countries.

Methodology: Drawing on the stimulus-organism-response (SOR) framework, the research model was tested using the partial least squares structural equation modeling (PLS-SEM) technique with a questionnaire applied to 731 respondents from Saudi Arabia.

Findings: The results showed that perceived quality, consumer satisfaction, and brand image have a positive impact on purchase intention, whereas perceived price could not explain purchase intention. Moreover, consumer satisfaction and brand image appeared to significantly mediate the relationships in the research model.

Research limitations: This article studies a specific country and local dairy consumption. One should be careful when generalizing the results to other food and country contexts.

Originality/value: This study investigates consumer purchase intention specifically toward local dairy products, which was a matter underexplored in the literature as opposed to studies on a variety of other local products. Moreover, the article contributes to an extension of the SOR framework onto the body of literature regarding local products.

Keywords: SOR theory, perceived quality, local products, consumer purchase intention, dairy products.

JEL: M31, C38

\footnotetext{
1 Anadolu University, Department of Marketing, Yeşiltepe, Yunus Emre Campus, 26470 Tepebaş/_Eskişehir, Turkey; e-mail: nadjim_mkedder@ anadolu.edu.tr.; https://orcid.org/ 0000-0002-4523-2038.

2 Corresponding author: Samsun University, Department of Aviation Management, İstiklal Denizevleri Str., 55420 0ndokuzmayıs/Samsun, Turkey; e-mail: mahmut.bakir@samsun.edu.tr; https://orcid.org/0000-0002-3898-4987.

3 University of Tlemcen, Department of Management, University Aboubekr Belkaid, 22, Abi Ayed Abdelkrim Street, BP119, 13000, Tlemcen, Algeria; https://orcid.org/0000-0002-5892-9985.
} 


\section{Introduction}

Over the recent decade, globalization has contributed to enormous changes in consumer preference for purchasing local or imported products. The improvement of world trade liberalization opened new markets and new opportunities for companies to distribute their products across several countries and drown the markets with various local and foreign products. Generally, foreign products refer to products distributed on a global scale and owned by foreign entities, while local products refer to products owned and distributed domestically (Winit et al., 2014). Previous research has revealed that both foreign and local products affect consumer preferences by country context (Yen, 2018). For example, in developed countries, consumers perceive local products as having better quality than their foreign counterparts. On the other hand, the literature posits that consumers in developing countries tend to buy foreign products for motivations such as material consumption, status, and prestige (Sharma, 2011).

The debate on whether a consumer prefers a local or foreign product is centered on various norms of country-of-origin (COO) effects such as the theory of ethnocentrism (Dutta et al., 2017; Baran, 2018; Prince, 2020), animosity (Souiden et al., 2018; Abrar et al., 2019), and consumer patriotism (Sharma, 2011; Götze and Brunner, 2019). The $\mathrm{COO}$ effect provides a bidirectional explanation for consumption patterns. Accordingly, either consumers support local products for such reasons as national pride, perception of freshness, and contribution to the country's economy or they have a strong preference toward foreign brands for such reasons as status, prestige, and quality perception (Winit et al., 2014; Baran, 2018).

The COO effect may arise in favor of foreign products in some cases and in favor of local products in other. One of the best examples of local product cases is dairy consumption. Nielsen's (2017) Global Brand-Origin Report shows that the most preferred local product category is dairy products, with $54 \%$. Identifying antecedents of consumer purchase intention is essential for researchers as it allows for the development of appropriate strategies for brands (Ali et al., 2018). However, despite the growing interest in local food consumption, studies on antecedents of purchasing local dairy products remain limited (Bousbia et al., 2017; Boubker and Douayri, 2020). At the same time, it appears that existing studies offer no comprehensive results while the literature lacks theory-driven research on local dairy products. Thus, in an effort to fill this research gap, this article aims to examine antecedents of purchase intention toward local dairy products in the context of Saudi Arabia, a developing country. To do so, we adopted the stimulus-organism-response (SOR) framework to address the research gap. Following the SOR theory, when a consumer is exposed to a variety of product characteristics, 
this stimulation can affect the consumer's psychological responses, and subsequently his or her purchasing decision or intention (Alam and Noor, 2020). Accordingly, we suggest that perceived price and perceived quality - frequently used local product characteristics (Shi et al., 2016) - are the main stimuli for local dairy products. Similarly, we identified brand image and customer satisfaction to measure the internal state of the consumer. Finally, purchase intention toward local dairy products represents the response to the stimulus and the organism. In this sense, the research questions this article seeks to answer are:

RQ1. What is the relationship between perceived quality (S), perceived price (S), customer satisfaction $(\mathrm{O})$, brand image $(\mathrm{O})$, and purchase intention $(\mathrm{R})$ ?

$R Q 2$. Do customer satisfaction $(\mathrm{O})$ and brand image $(\mathrm{O})$ mediate the relationship between perceived quality (S), perceived price (S), and purchase intention (R)?

The case and object of the research - namely Saudi Arabia as a developing country and dairy products - are justifiable in several respects. Shi et al. (2016) state that in developing countries, foreign brands are preferred more in anticipation of social status and prestige. However, as we mentioned above, consumer preferences in dairy products favor local products. Moreover, the preference rate for local dairy products is $69 \%$ among Saudi consumers, which is above the global average (Arab News, 2018). Second, Saudi Arabia is one of the countries that rely heavily on dairy imports (OECD and FAO, 2018) and there are many foreign dairy brands present in stores besides local brands. Considering Saudi Arabia's high level of income and spending on imported food, we regard it as a reasonable developing country case.

This article contributes to the literature in a few ways. This article advances the understanding of purchase intention by extending the SOR theory to local dairy consumption for the first time. Second, the presented study is one of the few limited studies addressing local food consumption in the Saudi Arabian context (Hussein and Hassan, 2018; Hasan and Sohail, 2020). Moreover, the factors affecting the purchase intention of Saudi consumers toward local dairy products remain underexplored.

The remainder of this article will proceed as follows. The second section will outline the conceptual background and formulate research hypotheses. Then, the third section will provide methodological aspects such as data collection and measurements. The results will be given in the fourth section and discussed in the fifth section by highlighting the managerial and theoretical implications. Finally, the sixth section will conclude and present limitations and possibilities of future research. 


\section{Conceptual Background and Hypotheses Development}

\section{The SOR Theory}

According to the SOR theory developed by Mehrabian and Russell (1974), stimulus (S) refers to variables that affect the internal state of consumers recognized as an organism (O), ultimately evoking observable responses (R; Xiao et al., 2019; Alam and Noor, 2020).

In the initial SOR framework, stimulus serves as any environmental hint such as product quality, prices, packages, or promotions that provoke hedonist responses of consumers through that environment (Eroglu et al., 2001; Liang and Lim, 2020). Previous studies considered perceived quality and perceived price as elements of environmental cues (Yen, 2018; Alam and Noor, 2020; Liang and Lim, 2020). For instance, Yen (2018) uses price and quality as environmental stimuli to investigate the consumer purchase intention in local products in developing countries. On the other hand, an organism may pertain to psychological states mediating between stimuli and the final responses of individuals (Liu et al., 2016). Since this inner state includes perceptual, physiological, and feeling activities, it is justifiable to conceptualize customer satisfaction and image as an organism, as proposed in the past literature (Famiyeh et al., 2018; Alam and Noor, 2020). Finally, response serves as the final outcome of individual actions, which can reflect positive or negative behavioral responses (Famiyeh et al., 2018). Purchase intention has been investigated in various studies as a response (Xiao et al., 2019; Suparno, 2020).

We adopted the SOR theory in this study to investigate purchase intention toward local dairy products in Saudi Arabia (see Figure 1). The application of this framework is considered sensible since it has previously been used to discuss purchase intention for different products and domains (Liu et al., 2019; Suparno, 2020), and it offers a structured manner for our study.

\section{Perceived Quality}

Perceived quality refers to "the consumer's judgment about the superiority or excellence of a product" (Zeithaml, 1988). Previous research established that perceived quality is a crucial factor in building consumer satisfaction (Su et al., 2019; Samudro et al., 2020). For instance, Sumaedi et al. (2011) demonstrate that consumers can be satisfied if the service they received exceeds their expectations. On the other hand, some interesting findings addressing the perception of quality also appeared in the literature, for instance in Hamin et al. (2014). Accordingly, in developed countries, consumers 
perceive local products as better quality than foreign products (Hamin et al., 2014). Similarly, local products, which are considered to be of higher quality in developing markets, increase the purchase intention of consumers (Yen, 2018).

In parallel, the association between perceived quality and brand image is also well established (Ali et al., 2018; Alkhawaldeh et al., 2020). Moreover, perceived quality represents a perception or aggregate emotions concerning a brand (Chakraborty, 2019). It assists in brand expansion, influences consumers to pay an immense amount of money for a product or service, offers a special position to the brand among other brands, and is the crucial cause for the purchase of a product or service (Aaker, 1991). The empirical results of Ali et al. (2018) hint that the halal ("permissible") brand image is significantly influenced by perceived brand quality. Thus, offering higher service quality is a good opportunity for local businesses that want to strengthen their brand image. The relationship between perceived quality and purchase intention was also been investigated. Scholars note that purchase intention is the decisive outcome of perceived quality (Liu et al., 2016; Ali et al., 2018; Yen, 2018). As stated by Yen (2018), perceived quality is the key factor that influences purchase intention, regardless of whether it refers to a local or imported product. Similarly, Ali et al. (2020) observe that perceived quality fosters consumer intention to buy from halal brands. Thus, this research proposes the following hypotheses:

H1: Perceived quality has a positive effect on customer satisfaction.

H2: Perceived quality has a positive effect on brand image.

H3: Perceived quality has a positive effect on purchase intention.

\section{Perceived Price}

Price is considered a pecuniary sacrifice for achieving a product (Zeithaml, 1988). Zeithaml (1988) proposes that individuals prefer not to estimate the thematic price of a product. Alternatively, consumers perceive the price by matching thematic price to reference price, which yields significant results (Zeithaml, 1988). Therefore, in this study, we posited that the perceived price is the consumer perception of a pecuniary sacrifice for attaining a product or service.

Commonly, consumers will not purchase a product if the price they have to pay is too high than what they will receive (Adi et al., 2019). In developing countries, consumers tend to perceive local products as having reasonable and depressed prices; this perception leads them to purchase local products and ignore imported products (Yen, 2018). According to Muskat et al. (2019), the perceived price can be deliberated by the 
suitability of the price to be driven. Therefore, the further reasonable or depressed the price of local products, the further satisfied the customer by the price of a product (Sumaedi et al., 2011). Similarly, Adi et al. (2019) demonstrate that perceived price positively influences customer satisfaction. Sumaedi et al. (2011) explore the impact of perceived quality and price on students' satisfaction. Their results show that students' perceived price is a strong predictor that affects students' satisfaction.

In the same vein, many studies addressed the effects of perceived price on brand image (Jin et al., 2012; Alhaddad, 2014; Dib and Awad Alhaddad, 2015). With the data collected from Toyota car consumers in Indonesia, Setiawan et al. (2016) examine the influence of price fairness on brand image and purchase intention. Their findings reveal that price fairness has a significant impact on brand image. Generally, when consumers sense that the prices provided are suitable and reasonable, they will constantly recall the brand at any time they make a purchase (Dib and Awad Alhaddad, 2015; Setiawan et al., 2016). Thus, if the perceived price of a local brand is reasonable then it can lead consumers to select local brands rather than competing foreign brands.

The mediating element between perceived price and purchase intention was also the subject of studies. Many studies mention that purchase intention is a critical outcome of perceived price (Kim et al., 2012; Lien et al., 2015; Yen, 2018). Kim et al. (2012) examine the effect of perceived price and trust in customer purchasing decisions in online shopping. Their findings show that perceived price significantly influences consumer purchase intention. The empirical study of Yen (2018) demonstrates that perceived price correlates with consumer eagerness to buy local products. Consumers may wish to purchase local dairy products if they perceive them as having a reasonable price. Thus, this research proposes the following hypothesis:

H4: Perceived price has a positive effect on customer satisfaction.

H5: Perceived price has a positive effect on brand image.

H6: Perceived price has a positive effect on purchase intention.

\section{Customer Satisfaction}

Satisfaction is the level of harmony between willingness and the actuality perceived from the perspective of consumer experience (Howard and Sheth, 1969). Given that consumers build expectations before purchasing a specific product, it is obvious that they will compare the perceived performance after consumption with their expectations (Kardes et al., 2011). At this point, satisfaction derives from the confirmation of these expectations, which implies that satisfied customers continue to purchase. A large 
body of literature has examined the relationship between satisfaction and purchase intention (Ali et al., 2018; Chen and Lin, 2019; Watanabe et al., 2019). Hossain et al. (2018) indicate that customer satisfaction positively affects purchase intention concerning consumer response toward QR codes. Ali et al. (2020) report that satisfaction from halal brand products is an important antecedent of purchase intention. In the same pattern, Watanabe et al. (2019) elucidate that customer satisfaction positively affects purchase intention. Thus, we propose the following hypothesis in the context of local dairy products:

H7: Customer satisfaction has a positive effect on purchase intention.

\section{Brand Image}

Brand image alludes to a consumer's mental image of a brand that correlates with the offer, and it includes a symbolic understanding linked to the appropriate characteristics of the brand (Ali et al., 2020). Brand image plays a pivotal role in enabling consumers to distinguish products or services from their counterparts (Chen et al., 2020). When a consumer appraises the local product before purchase, the image of local products usually gives an outer cue that may directly or indirectly influence purchase intentions. As suggested by the existing literature (Ali et al., 2018; Lee and Lee, 2018; Yen, 2018), if local products contain a high brand image, consumers may prioritize their purchase. Similarly, Chen et al. (2020) suggest that enhancing products' brand image as eco-friendly leads to increased purchase intention of consumers. Thus, this research suggests the following hypothesis:

H8: Brand image has a positive effect on purchase intention.

\section{The Mediating Role of Customer Satisfaction and Brand Image}

As mentioned earlier, since the organism mediates the relationship between stimuli and responses (Bagozzi, 1986; Liu et al., 2016), the SOR model can justify the examination of the mediating effect of customer satisfaction and brand image. When reviewing the literature, we observed that customer satisfaction mediates the relationship between quality and purchase intention (Bello et al., 2020). Rajaguru (2016) found that service quality in airlines increases the satisfaction level of passengers, which results in a positive influence on behavioral intention. Likewise, Ali et al. (2018) explore purchase intention in halal products as the result of perceived quality, which shows that customer satisfaction indirectly enhances this relationship. Regarding perceived price, Rajaguru (2016) notes that monetary value positively affects behavioral intention via passenger satisfaction. 
The empirical findings also confirm the mediating role of brand image in the consumer research literature (Ali et al., 2018; Alam and Noor, 2020). Alkhawaldeh et al. (2020) address the mediating role of brand image in the field of higher education, taking into account its antecedents and outcomes. In the context of the halal brand, Ali et al. (2018) report that perceived quality builds brand image and encourages consumers to purchase intention. Similarly, Setiawan et al. (2016) highlight the direct and indirect effect of brand image on purchase intention, with a focus on price fairness. Considering these findings, we propose to further examine the effect of perceived price and perceived quality on purchase intention through brand image. As such, this study examined the mediating effect of customer satisfaction and brand image in the context of local dairy products based on the following hypotheses:

H9a: Customer satisfaction mediates the relationship between perceived quality and purchase intention.

H9b: Customer satisfaction mediates the relationship between perceived price and purchase intention.

H10a: Brand image mediates the relationship between perceived quality and purchase intention.

H10b: Brand image mediates the relationship between perceived price and purchase intention.

Figure 1. Research model

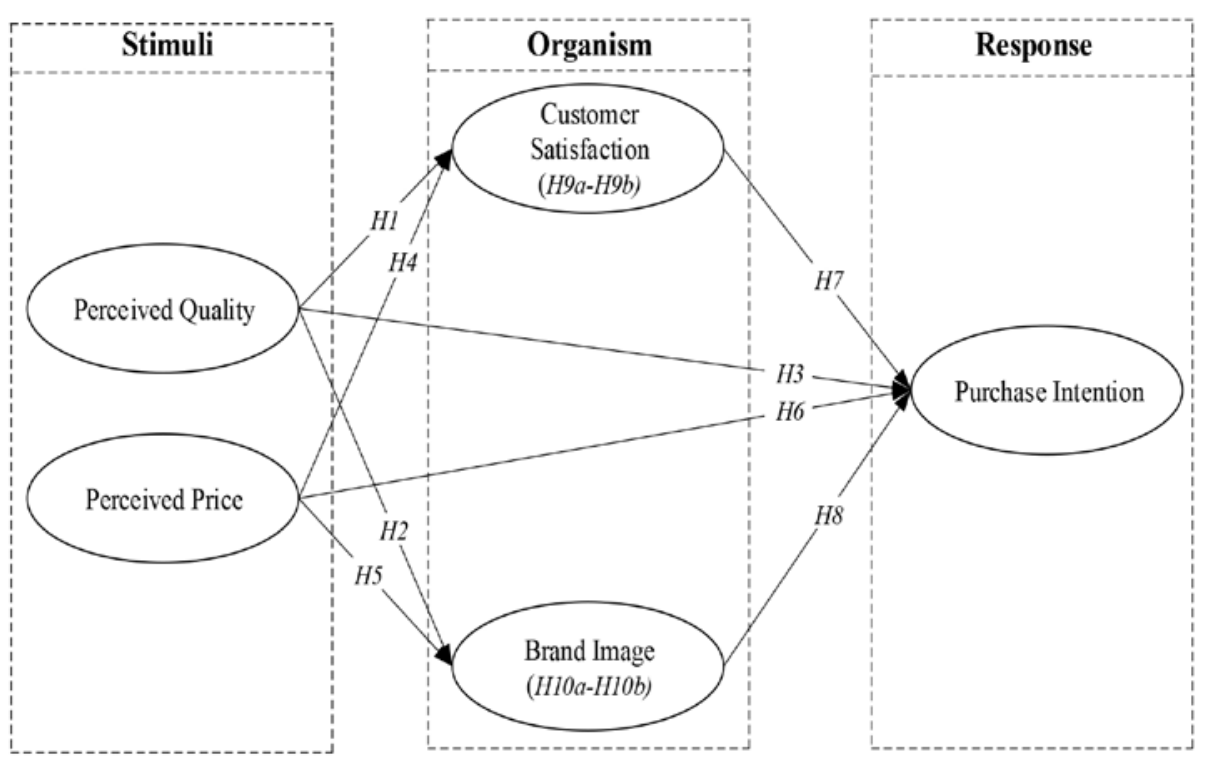

Source: own elaboration. 


\section{Research Method}

\section{Sampling and Data Collection Process}

In this study, target respondents were consumers living in Saudi Arabia. To increase the response rate, the respondents were targeted with the snowball sampling technique via a web-based questionnaire. The questionnaire was first distributed to students studying at Al Jouf University. Data was then collected over the March 2019 period. As suggested by recent developments (Hair et al., 2016), a priori power analysis was employed to find out the required minimum sample size. Using $\mathrm{G}^{*}$ Power software (v.3.1.9.2), the minimum sample size was found to be 85 at a statistical power level of 0.80 , the medium effect size (0.15) - with the significance level of 0.05 (Faul et al., 2007). After careful investigation, 731 valid responses were analyzed in this study as final data, after discarding incomplete and suspicious responses (i.e. straight-lining, zigzag patterns; Memon et al., 2020). Therefore, the final dataset was considered sufficient to investigate the proposed model. As Table 1 presents, the majority of respondents were women (67\%) who have an undergraduate degree (68.9\%), are aged 20-29 (61.1\%), and have an income of less than 3000 SR (63.2\%).

Table 1. Profile of respondents

\begin{tabular}{|l|c|c|}
\hline Demographic Characteristics & Frequency & Percentage \\
\hline Gender & & \\
\hline Male & 241 & 33.0 \\
\hline Female & 490 & 67.0 \\
\hline Education & & \\
\hline High school & 142 & 19.4 \\
\hline College & 61 & 8.3 \\
\hline Bachelor's & 504 & 68.9 \\
\hline Postgraduate & 24 & 3.3 \\
\hline Age & & \\
\hline Less than 20 years & 137 & 18.7 \\
\hline Between 20-29 & 447 & 61.1 \\
\hline Between 30-39 & 69 & 9.4 \\
\hline Between 40-49 & 63 & 8.6 \\
\hline Between 50-59 & 15 & 2.1 \\
\hline
\end{tabular}




\begin{tabular}{|c|c|c|}
\hline Income Level (in SR) & & \\
\hline Less than 3000 & 462 & 63.2 \\
\hline Between $3000-5000$ & 68 & 9.3 \\
\hline Between $5001-7000$ & 39 & 5.3 \\
\hline Between 7001-9000 & 38 & 5.2 \\
\hline Between 9001-12000 & 43 & 5.9 \\
\hline Over than 12000 & 81 & 11.1 \\
\hline
\end{tabular}

Note: SR denotes Saudi Riyal.

Source: own elaboration.

Finally, the non-response bias was also examined to uncover any systematical difference between the responses of the respondents (Armstrong and Overton, 1977). To examine this issue, two waves were created from the participants: early $(n=90)$ and late $(n=90)$ responses. No significant difference was identified between these waves with the independent t-test, thus confirming that there was no concern of non-response bias ( $p>0.05, n=731$; Gannon et al., 2020).

\section{Measurement}

The scales of the study were adapted from the previous research. Perceived quality and perceived price were drawn from Yen (2018). We examined customer satisfaction with five items taken from Aaker (1991) and Dai et al. (2015). Moreover, brand image was measured by using a five-item scale from Lien et al. (2015). Finally, we measured purchase intention toward local dairy products adapted from Yen (2018). When operationalizing constructs, items were slightly modified to the context of local dairy products. Since all scales are available in English, they were translated into Arabic by two native Arabic language experts using back translation method (Brislin, 1970). Then, through pre-testing, a small group of consumers confirmed - after minor corrections - that the items were understandable as intended and that there was no ambiguity. Each item was measured on a five-point Likert scale: from 1 = "completely disagree" to $5=$ "completely agree." Appendix A1 in the appendix outlines the construct items.

\section{Common Method Bias}

In self-report survey-based research, the common method bias (CMB) may inflate the estimated relationships. To identify any risk of the CMB, we first performed a full collinearity test proposed by Kock and Lynn (2012), regressing a random dummy 
variable on all research constructs. As Table 2 shows, the variance inflation factor (VIF) estimates were lower than 3.3, thus indicating that there was no pervasive threat. Through Harman's single-factor test, we confirmed that the CMB was not a serious issue because no single factor was extracted, and the variance of the unique factor explained was only $41.51 \%$ of the total variance (Gannon et al., 2020; Memon et al., 2020).

Table 2. Full collinearity test results

\begin{tabular}{|l|c|c|c|c|c|}
\hline & PQ & PP & SAT & BRI & PUI \\
\hline VIF & 2.369 & 1.547 & 2.364 & 2.344 & 1.708 \\
\hline
\end{tabular}

Note. $\mathrm{PQ}=$ Perceived quality, $\mathrm{PP}=$ Perceived price, $\mathrm{SAT}=$ Customer satisfaction, $\mathrm{BRI}=$ Brand image, $\mathrm{PUI}=$ Purchase intention.

Source: own elaboration.

\section{Data Analysis and Findings}

In the analysis of the proposed model, a partial least squares structural equation modeling (PLS-SEM) approach was employed using SmartPLS (v.3.3.2). The use of the PLS-SEM approach was justifiable for three reasons. First, the PLS-SEM has higher statistical power in examining hypothesized relationships. Second, it generates a more robust output for indirect effects than ordinary regression analysis (Sarstedt et al., 2020). Finally, it successfully handles complex models with large sample sizes (Alam and Noor, 2020; Hair et al., 2019). In the PLS analysis, we followed the two-stage procedure consisting of measurement and structural model evaluation (Ramayah et al., 2018).

Although PLS-SEM does not have a normal distribution assumption, normally distributed data gives more accurate results (Hair et al., 2019). This study examined data normality with indicators of skewness and kurtosis. Because the skewness and kurtosis values of the items ranged between -2 to +2 , the normality of the data was not a cause for concern (Nisar et al., 2021).

\section{Measurement Model Assessment}

The measurement model is related to internal consistency, convergent validity, and discriminant validity. Cronbach's alpha and composite reliability (CR) are employed to measure the internal consistency of the constructs. According to Hair et al. (2019), 
Cronbach's $\alpha$ coefficient reflects the lower bound of constructs' internal consistency, while CR shows the upper bound. As Table 3 depicts, our study achieved a satisfactory reliability level because Cronbach's $\alpha$ and CR values exceeded the threshold of 0.70 (Gilal et al., 2020; Liu et al., 2019).

Convergent validity should be examined using outer loadings ( $>0.708)$ and the average variance extracted (AVE) of constructs ( $>0.50$; Hair et al., 2016). As Table 3 shows, four items were below the acceptable threshold. However, since the AVE values were above the desired threshold, these items were not discarded and convergent validity was established (Ramayah et al., 2018).

Table 3. Measurement model assessment

\begin{tabular}{|c|c|c|c|c|c|}
\hline Constructs & Items & Loadings & Cronbach's $\alpha$ & CR & AVE \\
\hline \multirow[t]{7}{*}{ Perceived Quality } & $\mathrm{PQ1}$ & 0.628 & 0.86 & 0.893 & 0.545 \\
\hline & $P Q 2$ & 0.680 & & & \\
\hline & PQ3 & 0.797 & & & \\
\hline & PQ4 & 0.786 & & & \\
\hline & $\mathrm{PQ5}$ & 0.758 & & & \\
\hline & PQ6 & 0.722 & & & \\
\hline & PQ7 & 0.780 & & & \\
\hline \multirow[t]{3}{*}{ Perceived Price } & PP1 & 0.903 & 0.748 & 0.858 & 0.674 \\
\hline & PP2 & 0.910 & & & \\
\hline & PP3 & 0.615 & & & \\
\hline \multirow[t]{5}{*}{$\begin{array}{l}\text { Customer } \\
\text { Satisfaction }\end{array}$} & SAT1 & 0.879 & 0.852 & 0.893 & 0.629 \\
\hline & SAT2 & 0.882 & & & \\
\hline & SAT3 & 0.844 & & & \\
\hline & SAT4 & 0.700 & & & \\
\hline & SAT5 & 0.625 & & & \\
\hline \multirow[t]{5}{*}{ Brand Image } & BRI1 & 0.831 & 0.871 & 0.907 & 0.661 \\
\hline & BRI2 & 0.835 & & & \\
\hline & BRI3 & 0.797 & & & \\
\hline & BRI4 & 0.757 & & & \\
\hline & BRI5 & 0.840 & & & \\
\hline
\end{tabular}




\begin{tabular}{|l|l|l|l|l|l|}
\hline Purchase Intention & PUI1 & 0.893 & 0.898 & 0.936 & 0.831 \\
\hline & PUI2 & 0.941 & & \\
\hline & PUI3 & 0.901 & & \\
\hline
\end{tabular}

Source: own elaboration.

In the last step, we checked for discriminant validity by applying both Fornell's and Larcker's (1981) criterion and the heterotrait-monotrait (HTMT) ratio. Although the extant literature relies heavily on Fornell's and Larcker's (1981) criterion, Henseler et al. (2015) has recently proposed the HTMT ratio as a more robust tool in ensuring discrimination validity. As Table 4 reveals, both procedures established the discriminant validity of our constructs.

Table 4. Results of the discriminant analysis

\begin{tabular}{|c|c|c|c|c|c|c|c|c|c|c|}
\hline \multirow{2}{*}{ Constructs } & \multicolumn{5}{|c|}{ Fornell-Larcker criterion } & \multicolumn{5}{|c|}{ Heterotrait-monotrait ratio (HTMT) } \\
\hline & $P Q$ & PP & SAT & BRI & PUI & $\mathbf{P Q}$ & PP & SAT & BRI & PUI \\
\hline$P Q$ & 0.738 & & & & & & & & & \\
\hline PP & 0.520 & 0.821 & & & & 0.649 & & & & \\
\hline SAT & 0.663 & 0.497 & 0.793 & & & 0.745 & 0.581 & & & \\
\hline BRI & 0.686 & 0.549 & 0.655 & 0.813 & & 0.782 & 0.672 & 0.729 & & \\
\hline PUI & 0.552 & 0.371 & 0.608 & 0.514 & 0.911 & 0.632 & 0.445 & 0.674 & 0.578 & \\
\hline
\end{tabular}

Source: own elaboration.

\section{Structural Model Assessment}

In the PLS-SEM, the structural model evaluation is based on the $R^{2}$ (coefficient of determination), $f^{2}$ (effect size), $Q^{2}$ (predictive relevance), and the estimation of path coefficients (Hair et al., 2016). Table 5 shows that the proposed model explained 47.1\% of the variance of customer satisfaction and $52.1 \%$ of brand image. Moreover, antecedents of purchase intention were responsible for $41.4 \%$ of the variance. Thus, we were able to conclude that the model yielded satisfactory explanation power as the existing literature considers values above 0.20 significant in consumer research (Hair et al., 2016). Next, $f^{2}$ measures the magnitude of the change in $R^{2}$ if any construct is removed from the model (Hair et al., 2019). Cohen (1992) assigned the cut-offs of 0.02, 0.15 , and 0.35 for small, moderate, and large effects, respectively. Table 6 shows that 
two large effects and five small effects were observed in seven significant paths. Moreover, the predictive ability of the model was measured by Stone-Geisser's $Q^{2}$ value. Since $Q^{2}$ values were greater than zero, we inferred that the research model had sufficient predictive relevance (Hair et al., 2019; Memon et al., 2020; see Table 5).

Lastly, the goodness-of-fit (GoF) of the model was calculated using the global GoF metric (Tenenhaus et al., 2005). As we may see in Table 5, a satisfactory model fit was achieved as the GoF value was higher than the cut-off of 0.36 , thus indicating a large effect (Chen and Lin, 2019). Moreover, the standardized root mean square residual (SRMR) index was below 0.08, confirming satisfactory model fit (Hair et al., 2016).

Table 5. Results of the prediction power

\begin{tabular}{|l|l|l|l|l|}
\hline \multicolumn{1}{|c|}{ Hypothesis } & $\boldsymbol{R}^{\mathbf{2}}$ & $\boldsymbol{Q}^{\mathbf{2}}$ & GoF value & SRMR \\
\hline Perceived Quality & & & \\
\hline Perceived Price & & & \\
\hline Customer Satisfaction & 0.471 & 0.286 & 0.548 & 0.075 \\
\hline Brand Image & 0.521 & 0.339 & \\
\hline Purchase Intention & 0.414 & 0.339 & \\
\hline
\end{tabular}

Source: own elaboration.

As Table 6 shows, since the variance inflation factor (VIF) values were below 3 - indicating that multicollinearity is not a critical issue - we proceeded to examine the significance of path coefficients (Hair et al., 2019). In the examination of the hypothesized relationships, the bootstrapping procedure was applied using 5000 resamples (Hair et al., 2016). Table 6 and Figure 2 provide the outputs of the hypotheses testing. Accordingly, seven of the eight hypotheses were accepted. In particular, perceived quality showed to have a positive impact on consumer satisfaction $(\beta=0.554, p<0.01)$, brand image $(\beta=0.549, p<0.01)$, and purchase intention $(\beta=0.217, p<0.01)$. Moreover, perceived price showed to have a positive impact on consumer satisfaction $(\beta=0.209, p<0.01)$ and brand image $(\beta=0.264, p<0.01)$. However, the effect of perceived price on purchase intention was found to be insignificant ( $\beta=0.005, p=0.907$ ). Therefore, unlike the supported $\mathrm{H} 4$ and $\mathrm{H} 5, \mathrm{H} 6$ was rejected. The outputs also confirmed that the impact of both customer satisfaction $(\beta=0.392, p<0.01)$ and brand image $(\beta=0.106, p<0.05)$ on purchase intention were significant, providing support for $\mathrm{H7}$ and $\mathrm{H} 8$. 
Table 6. Results of hypotheses testing

\begin{tabular}{|c|c|c|c|c|c|c|c|c|}
\hline Hypotheses & $\beta$ & SE & t-statistics & p-value & $\begin{array}{c}\text { Bias } \\
\text { Corrected } \\
\text { Cl }(95 \%)\end{array}$ & Decision & $f^{2}$ & VIF \\
\hline $\mathrm{H} 1: \mathrm{PQ} \rightarrow \mathrm{SAT}$ & 0.554 & 0.034 & 16.355 & 0.000 & $\begin{array}{c}{[0.484,} \\
0.616]\end{array}$ & Supported & 0.423 & 1.371 \\
\hline $\mathrm{H} 2: \mathrm{PQ} \rightarrow \mathrm{BRI}$ & 0.549 & 0.032 & 16.950 & 0.000 & $\begin{array}{c}{[0.480,} \\
0.610]\end{array}$ & Supported & 0.459 & 1.371 \\
\hline H3: PQ $\rightarrow$ PUI & 0.217 & 0.051 & 4.252 & 0.000 & $\begin{array}{l}{[0.115,} \\
0.316]\end{array}$ & Supported & 0.035 & 2.289 \\
\hline $\mathrm{H} 4: \mathrm{PP} \rightarrow \mathrm{SAT}$ & 0.209 & 0.036 & 5.849 & 0.000 & $\begin{array}{l}{[0.140,} \\
0.282]\end{array}$ & Supported & 0.060 & 1.371 \\
\hline H5: PP $\rightarrow$ BRI & 0.264 & 0.041 & 6.420 & 0.000 & $\begin{array}{l}{[0.180,} \\
0.342]\end{array}$ & Supported & 0.106 & 1.371 \\
\hline H6: $\mathrm{PP} \rightarrow \mathrm{PUI}$ & 0.005 & 0.041 & 0.116 & 0.907 & $\begin{array}{c}{[-0.075} \\
0.085]\end{array}$ & Rejected & 0.000 & 1.547 \\
\hline H7: SAT $\rightarrow$ PUI & 0.392 & 0.044 & 8.983 & 0.000 & $\begin{array}{c}{[0.301,} \\
0.470]\end{array}$ & Supported & 0.125 & 2.101 \\
\hline $\mathrm{H} 8: \mathrm{BRI} \rightarrow \mathrm{PUI}$ & 0.106 & 0.047 & 2.288 & 0.022 & $\begin{array}{l}{[0.015,} \\
0.199]\end{array}$ & Supported & 0.008 & 2.324 \\
\hline
\end{tabular}

Source: own elaboration.

Figure 2. Structural model output from SmartPLS 3.3.2

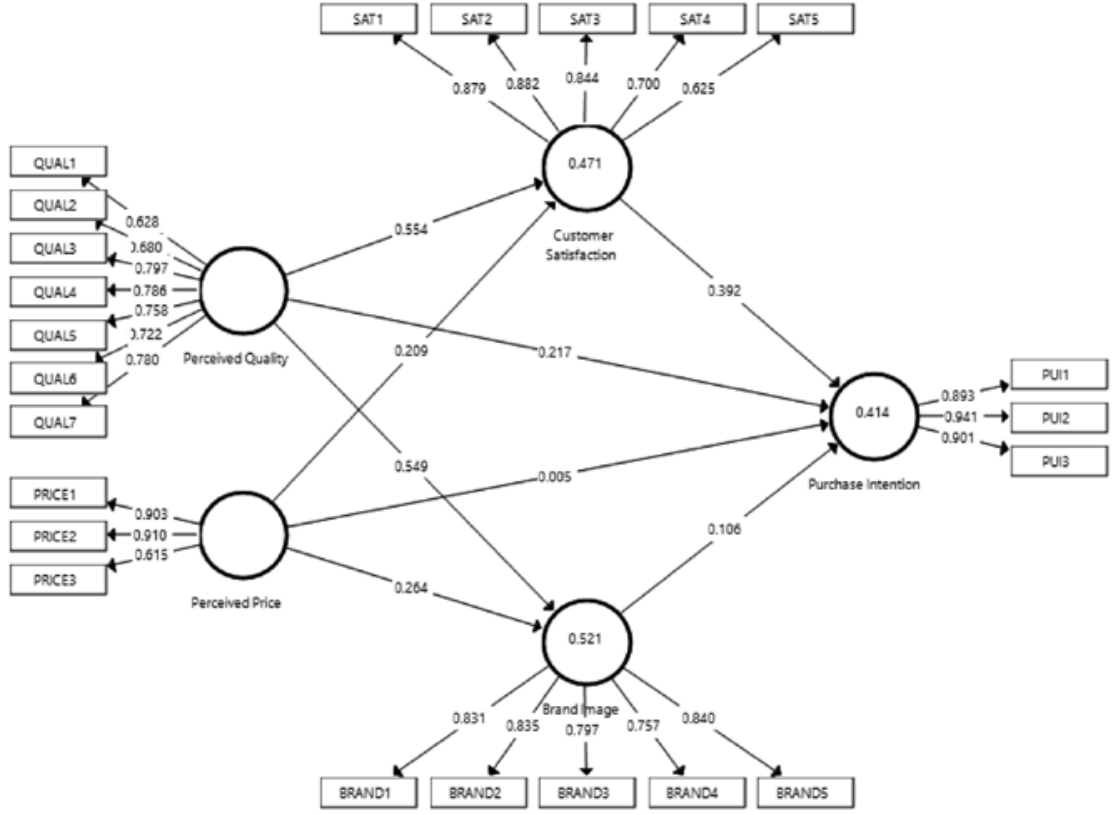

Source: own elaboration in SmartPLS software. 


\section{Mediating Effect Assessment}

Further analysis was performed to examine the mediating effects through the bias-corrected procedure of bootstrap confidence intervals with 5000 resamples (Ramayah et al., 2018). In this method, lower limit (LL) and upper limit (UL) values of the confidence interval should not contain zero for a significant mediating effect (Memon et al., 2020). As Table 7 shows, customer satisfaction proved to mediate the impact of perceived quality (H9a: $\beta=0.217, t=8.497$, CI: [LL $=0.169$, $\mathrm{UL}=0.268]$ ) and perceived price (H9b: $\beta=0.082, t=4.744$, CI: [LL $=0.051$, UL $=0.120]$ ) on purchase intention. Similarly, brand image proved to mediate the effect of perceived quality (H10a: $\beta=0.058$, $t=2.232$, CI: [LL $=0.008, \mathrm{UL}=0.110]$ ) and perceived price (H10b: $\beta=0.028, t=2.195$, CI: $[\mathrm{LL}=0.005$, UL $=0.056])$ on purchase intention. Hence, we confirmed that the mediating effects are statistically significant.

Table 7. Results of mediating effect analysis

\begin{tabular}{|c|c|c|c|c|c|c|}
\hline Hypotheses & B & SE & t-statistics & p-value & $\begin{array}{c}\text { Bias } \\
\text { Corrected } \\
\text { CI (95\%) }\end{array}$ & Decision \\
\hline H9a: $\mathrm{PQ} \rightarrow \mathrm{SAT} \rightarrow \mathrm{PUI}$ & 0.217 & 0.026 & 8.497 & 0.000 & $\begin{array}{l}{[0.169,} \\
0.268]\end{array}$ & Supported \\
\hline $\mathrm{H} 9 \mathrm{~b}: \mathrm{PP} \rightarrow \mathrm{SAT} \rightarrow \mathrm{PUI}$ & 0.082 & 0.017 & 4.744 & 0.000 & $\begin{array}{c}{[0.051,} \\
0.120]\end{array}$ & Supported \\
\hline $\mathrm{H} 10 \mathrm{a}: \mathrm{PQ} \rightarrow \mathrm{BRI} \rightarrow \mathrm{PUI}$ & 0.058 & 0.026 & 2.232 & 0.026 & $\begin{array}{c}{[0.008,} \\
0.110]\end{array}$ & Supported \\
\hline H10b: $\mathrm{PP} \rightarrow \mathrm{BRI} \rightarrow \mathrm{PUI}$ & 0.028 & 0.013 & 2.195 & 0.028 & $\begin{array}{c}{[0.005,} \\
0.056]\end{array}$ & Supp \\
\hline
\end{tabular}

Source: own elaboration.

\section{Discussion}

As section 4.2 delineates, our empirical results show that perceived quality has a significant positive effect on consumer satisfaction, brand image, and purchase intention, thus confirming H1, H2, and H3. These findings are consistent with prior studies (Ali et al., 2018; Samudro et al., 2020; Yen, 2018). In their study on halal brands, Ali et al. (2018) find that perceived quality affects brand image and customer satisfaction and subsequently affects purchase intention. Yen (2018) reports that perceived quality is the strongest predictor of purchase intention toward domestic products. This study 
recognized the role of perceived quality of local dairy products on customer satisfaction, brand image, and purchase intention, which the existing literature neglected to address so far. Therefore, we can infer that perceived quality is essential for a strong brand image and high customer satisfaction, while subsequently for enhanced purchase intention.

The research model attempted to reveal the role of the perceived price. Accordingly, $\mathrm{H} 4$ and $\mathrm{H} 5$ are supported in the statement that perceived price has a significant positive effect on consumer satisfaction and brand image. These findings agree with previous studies (Adi et al., 2019; Setiawan et al., 2016). In the context of another product, Setiawan et al. (2016) find that justifiable price positively affects brand image. Muskat et al. (2019) highlight the importance of perceived price for increasing satisfaction. These findings highlight the role of the perceived price of local dairy products to build strong brands and strengthen customer satisfaction.

On the other hand, this study failed to find the significant effect of perceived price on purchase intention posited by H6. Indeed, the effect of perceived price on purchase intention in the literature is contradictory. For example, while some studies observe a significant relationship between the two (Lien et al., 2015; Setiawan et al., 2016; Yen, 2018), another research stream (Jitrawang and Krairit, 2019; Muskat et al., 2019) finds that perceived price does not drive purchase intention. As a possible explanation, McKinsey's survey report (2018) states that Saudi consumers attach more importance to quality than price. Moreover, the existing literature suggests that consumers tend to choose local brands - even if expensive - with motivations of supporting their country's culture and economy and consuming quality products (Winit et al., 2014).

Moreover, our empirical results suggest the positive impact of customer satisfaction and brand image on purchase intention, thus confirming $\mathrm{H} 7$ and H8. These findings agree with those obtained by Ali et al. and Watanabe et al. (Ali et al., 2018; Watanabe et al., 2019). Ali et al. (2020) report the direct impact of brand image and customer satisfaction on purchasing intention in the context of halal products. Accordingly, consumers can continue to buy if their satisfaction levels are high. On the other hand, brand image present in consumers' minds enables them to distinguish local products from their foreign counterparts. Saudi consumers encounter dozens of different brands every day. If local products build a positive image in their eyes, they will be positively driven by this in purchase decisions.

Furthermore, our findings elucidated the mediating effect that customer satisfaction and brand image exert on the relationships investigated. The existing literature established 
the mediating role of brand image and customer satisfaction for various variables (Bello et al., 2020; Chen et al., 2020; Li et al., 2020; Muskat et al., 2019). More recently, Ali et al. (2020) have demonstrated the mediating effect of brand image and brand satisfaction between perceived quality and purchase intention in the context of halal milk brands. As mentioned earlier, the organism mediates the relationship between stimuli and responses in the SOR framework (Bagozzi, 1986). In this sense, this study confirms the mediating effect of customer satisfaction $(\mathrm{O})$ and brand image $(\mathrm{O})$ between perceived quality (S) and perceived price (S) juxtaposed to purchase intention (R).

\section{Conclusions}

\section{Theoretical Implications}

This study focuses on antecedents of purchase intention toward local dairy products in Saudi Arabia in the context of developing countries. Drawing on the SOR framework, we examined the relationships between perceived price (S), perceived quality (S), brand image (O), satisfaction (O), and purchase intention (R). Therefore, this study adds to the existing literature on consumer purchase behavior of local products in several ways.

Until now, research dealing with purchase intention toward local products focused on factors such as consumer ethnocentrism, nationalism, and patriotism (Abrar et al., 2019; Dutta et al., 2017). However, this study proposed a new model based on the SOR theory by incorporating basic local product characteristics such as perceived quality and perceived price with customer satisfaction and brand image. In this regard, this is the first study to extend the SOR framework to the local dairy consumption literature, meaning that we applied the SOR theory in a new context. Moreover, this model confirmed the mediating effect of customer satisfaction and brand image.

The developed-developing countries dichotomy attracted the attention of local and foreign product consumption literature. Many studies investigate local product consumption in developing and developed countries (Ali et al., 2018; Götze and Brunner, 2019; Shi et al., 2016). In this regard, this study is one of the few studies focusing on the consumption of local products in the Saudi Arabian context (Hasan and Sohail, 2020; Hussein and Hassan, 2018). Moreover, it is the first attempt to investigate the purchase intention of Saudi consumers for local dairy products. 


\section{Managerial Implications}

The results offer managerial implications to marketers, local dairy producers, and retailers in Saudi Arabia. Saudi Arabia is a developing market where both local and foreign dairy products appear, and competition is intense. Under such conditions of fierce competition, firms should understand why consumers prefer domestic or foreign products in order to develop effective marketing strategies. Therefore, this study advances the understanding of consumer purchase intention for companies in the market.

This research shows that the low perceived quality clearly affects consumer purchase intention. Nevertheless, ignoring local dairy brands' perception of quality could have dire consequences for their sales. Local firms should increase their attention to perceived quality so as to improve purchase intention toward local dairy products, thus increasing market share. In order to increase the sales of foreign dairy products, marketers can develop new market penetration strategies such as promotion, free product experience, and increase in the perception of product quality, while seeking to reduce the visibility of the country of origin.

Noteworthy, perceived quality is also important in terms of enhancing customer satisfaction and brand image as it boosts purchase intention (Ali et al., 2018). On the other hand, perceived price does not directly affect the purchase intention of consumers. Therefore, local and foreign producers and retailers should not base their marketing strategies on low prices. However, we should not forget that the desired perceived price will contribute to increasing consumer purchase intention by enhancing customer satisfaction and brand image. Foreign firms should create communication campaigns that reinforce the perceived quality perception instead of sales promotion. If foreign brands create a strong quality perception, it can lead to greater competitive advantage and increased profitability in the Saudi Arabian market. In this respect, our findings may help firms to maximize their profits.

\section{Limitations and Future Research}

There are limitations to our study that should be addressed in future studies. This study's sample gathered relatively young and educated consumers from Al-Jouf, one of the largest cities in the north of Saudi Arabia. Furthermore, the findings reflect local dairy consumption preferences. Therefore, we should be careful when generalizing these study results to other food categories. As we mentioned above, in developed and developing countries, local product preferences and attitudes may change. Therefore, future research should provide fresh insights by comparing local dairy consumption 
in developing and developed countries with methods such as multi-group analysis. On the other hand, this study used perceived quality and perceived price as stimuli and customer satisfaction and brand image as organisms. We recommend that future studies consider other factors such as perceived value. What is also worth further examination is the role of materialism in dairy consumption in the context of developing countries as materialistic feelings are increasing in developing countries (Shi et al., 2016). Finally, this study examined consumer purchase intention built on a research model through a cross-sectional design. The use of different qualitative and quantitative analyses in the future may provide different insights into local product consumption.

\section{References}

Aaker, D.A. (1991). Managing brand equity: capitalizing on the value of a brand name. Free Press.

Abrar, M., Shabbir, R., Hussain, I., and Din, S. (2019). Impact of Customer Animosity and Attitude on Purchase Intention in Fast-Food Industry of Pakistan. Pakistan Journal of Social Sciences, 39(3), 959-969.

Adi, P.H., Dhiaulhaq, M.I., and Novandari, W. (2019). Customer Satisfaction As The Moderating Variable Of Customer Loyalty. Jurnal Akuntansi Manajemen Dan Ekonomi, 21(1), 13-22. https://doi.org/10.32424/1.JAME.2019.21.1.1432.

Alam, M.M.D., and Noor, N.A.M. (2020). The Relationship Between Service Quality, Corporate Image, and Customer Loyalty of Generation Y: An Application of SOR Paradigm in the Context of Superstores in Bangladesh. SAGE Open, 10(2), 1-19. https://doi.org/10.1177/2158244020924405.

Alhaddad, A. (2014). Does Price Awareness Matter to Brand Equity ? European Journal of Economics, Finance and Administrative Sciences, 65, 21-27.

Ali, A., Sherwani, M., Ali, A., Ali, Z., and Sherwani, M. (2020). Investigating the antecedents of halal brand product purchase intention: an empirical investigation. Journal of Islamic Marketing. https://doi.org/10.1108/JIMA-03-2019-0063.

Ali, A., Xiaoling, G., Sherwani, M., and Ali, A. (2018). Antecedents of consumers' Halal brand purchase intention: an integrated approach. Management Decision, 56(4), 715-735.

https://doi.org/10.1108/MD-11-2016-0785.

Alkhawaldeh, A., Alsaad, A., Taamneh, A., and Alhawamdeh, H. (2020). Examining antecedents and consequences of university brand image. Management Science Letters, 10(5), 953-960. https://doi.org/10.5267/j.msl.2019.11.016.

Arab News (2018). Saudi consumers more inclined to purchase local food products, says survey. Obtained from: https://www.arabnews.com/node/1218606/corporate-news.

Armstrong, J.S., and Overton, T.S. (1977). Estimating Nonresponse Bias in Mail Surveys. Journal of Marketing Research, 14(3), 396-402. https://doi.org/10.2307/3150783.

Bagozzi, R.P. (1986). Attitude formation under the theory of reasoned action and a purposeful behaviour reformulation. British Journal of Social Psychology, 25(2), 95-107.

https://doi.org/10.1111/j.2044-8309.1986.tb00708.x.

Baran, R. (2018). Characteristics of cosmetics brands by country of origin according to the opinion of polish consumers. Journal of Management and Business Administration. Central Europe, 26(3), 2-13. https://doi.org/10.7206/jmba.ce.2450-7814.232. 
Bello, K.B., Jusoh, A., and Md Nor, K. (2020). Relationships and impacts of perceived CSR, service quality, customer satisfaction and consumer rights awareness. Social Responsibility Journal. https://doi.org/10.1108/SRJ-01-2020-0010.

Boubker, O., and Douayri, K. (2020). Dataset on the relationship between consumer satisfaction, brand attitude, brand preference and purchase intentions of dairy product: The case of the Laayoune-Sakia El Hamra region in Morocco. Data in Brief, 32. https://doi.org/10.1016/j.dib.2020.106172.

Bousbia, A., Boudalia, S., Chelia, S., Oudaifia, K., Amari, H., Benidir, M., Belkheir, B., and Hamzaoui, S. (2017). Analysis of Factors Affecting Consumer Behavior of Dairy Products in Algeria: A Case Study from the Region of Guelma. International Journal of Agricultural Research, 12(2), 93-101. https://doi.org/10.3923/ijar.2017.93.101.

Brislin, R.W. (1970). Back-translation for cross-cultural research. Journal of Cross-Cultural Psychology, 1(3), 185-216. https://doi.org/10.1177/135910457000100301.

Chakraborty, U. (2019). The impact of source credible online reviews on purchase intention: The mediating roles of brand equity dimensions. Journal of Research in Interactive Marketing, 13(2), 142-161. https://doi.org/10.1108/JRIM-06-2018-0080.

Chen, S.C., and Lin, C.P. (2019). Understanding the effect of social media marketing activities: The mediation of social identification, perceived value, and satisfaction. Technological Forecasting and Social Change, 140, 22-32. https://doi.org/10.1016/j.techfore.2018.11.025.

Chen, Y.S., Huang, A.F., Wang, T.Y., and Chen, Y.R. (2020). Greenwash and green purchase behaviour: the mediation of green brand image and green brand loyalty. Total Quality Management and Business Excellence, 31(1-2), 194-209. https://doi.org/10.1080/14783363.2018.1426450.

Cohen, J. (1992). A Power Primer. Psychological Bulletin, 112(1), 155-159. https://doi.org/10.1037/0033-2909.112.1.155.

Dai, H., Luo, X., Liao, Q., and Cao, M. (2015). Explaining consumer satisfaction of services: The role of innovativeness and emotion in an electronic mediated environment. Decision Support Systems, 70, 97-106. https://doi.org/10.1016/j.dss.2014.12.003.

Dib, H., and Awad Alhaddad, A. (2015). Determinants of Brand Image in Social Media. International Journal of E-Education, e-Business, e-Management and e-Learning, 5(4), 180-190. https://doi.org/10.17706/ijeeee.2015.5.4.180-190.

Dutta, S., Yaprak, A., and Grewal, D. (2017). Fairness perceptions of retail price increases by foreign and domestic brands: The roles of ethnocentric beliefs, profit stickiness, and contextual information. Journal of Business Research, 75, 37-45. https://doi.org/10.1016/j.jbusres.2017.02.004.

Eroglu, S.A., Machleit, K.A., and Davis, L. M. (2001). Atmospheric qualities of online retailing: A conceptual model and implications. Journal of Business Research, 54(2), 177-184. https://doi.org/10.1016/S0148-2963(99)00087-9.

Famiyeh, S., Asante-Darko, D., and Kwarteng, A. (2018). Service Quality, Customer Satisfaction, and Loyalty in the Banking Sector: The Moderating Role of Organizational Culture. International Journal of Quality and Reliability Management, 35(8), 1546-1567. https://doi.org/10.1108/IJQRM-01-2017-0008.

Faul, F., Erdfelder, E., Lang, A.G., and Buchner, A. (2007). G*Power 3: A Flexible Statistical Power Analysis Program for the Social, Behavioral, and Biomedical Sciences. Behavior Research Methods, 39(2), 175-191. https://doi.org/10.3758/BF03193146.

Fornell, C., and Larcker, D.F. (1981). Evaluating Structural Equation Models with Unobservable Variables and Measurement Error. Journal of Marketing Research, 18(1), 39-50. https://doi.org/10.2307/3151312.

Gannon, M., Rasoolimanesh, S.M., and Taheri, B. (2020). Assessing the Mediating Role of Residents' Perceptions toward Tourism Development. Journal of Travel Research, 1-23.

https://doi.org/10.1177/0047287519890926. 
Gilal, F.G., Gadhi, A.K., Gilal, R.G., Gilal, N.G., Zhang, N., and Gong, Z. (2020). Towards an Integrated Model of Customer Religiosity: A Self-Determination Theory Perspective. Central European Management Journal, 28(2), 16-37. https://doi.org/10.7206/cemj.2658-0845.20.

Götze, F., and Brunner, T.A. (2019). Sustainability and country-of-origin: How much do they matter to consumers in Switzerland? British Food Journal, 122(1), 291-308. https://doi.org/10.1108/BFJ-06-2018-0401.

Hair, J.F., Hult, G.T.M., Ringle, C.M., and Sarstedt, M. (2016). A Primer on Partial Least Squares Structural Equation Modeling (PLS-SEM) (2nd ed.). SAGE Publications, Inc.

Hair, J.F., Risher, J.J., Sarstedt, M., and Ringle, C.M. (2019). When to use and how to report the results of PLS-SEM. European Business Review, 31(1), 2-24. https://doi.org/10.1108/EBR-11-2018-0203.

Hamin, H., Baumann, C., and L. Tung, R. (2014). Attenuating double jeopardy of negative country of origin effects and latecomer brand: An application study of ethnocentrism in emerging markets. Asia Pacific Journal of Marketing and Logistics, 26(1), 54-77. https://doi.org/10.1108/APJML-07-2013-0090.

Hasan, M., and Sohail, M.S. (2020). The Influence of Social Media Marketing on Consumers' Purchase Decision: Investigating the Effects of Local and Nonlocal Brands. Journal of International Consumer Marketing, 1-18. https://doi.org/10.1080/08961530.2020.1795043.

Henseler, J., Ringle, C.M., and Sarstedt, M. (2015). A new criterion for assessing discriminant validity in variance-based structural equation modeling. Journal of the Academy of Marketing Science, 43(1), 115-135. https://doi.org/10.1007/s11747-014-0403-8.

Hossain, M.S., Zhou, X., and Rahman, M.F. (2018). Examining the impact of QR codes on purchase intention and customer satisfaction on the basis of perceived flow. International Journal of Engineering Business Management, 10, 1-11. https://doi.org/10.1177/1847979018812323.

Howard, J.A., and Sheth, J.N. (1969). The theory of buyer behavior. Wiley.

Hussein, R., and Hassan, S. (2018). Antecedents of Global Brand Purchase Likelihood: Exploring the Mediating Effect of Quality, Prestige and Familiarity. Journal of International Consumer Marketing, 30(5), 288-303. https://doi.org/10.1080/08961530.2018.1455549.

Jin, N., Lee, S., and Huffman, L. (2012). Impact of Restaurant Experience on Brand Image and Customer Loyalty: Moderating Role of Dining Motivation. Journal of Travel and Tourism Marketing, 29(6), 532-551. https://doi.org/10.1080/10548408.2012.701552.

Jitrawang, P., and Krairit, D. (2019). Factors Influencing Purchase Intention of Organic Rice in Thailand. Journal of Food Products Marketing, 25(8), 805-828. https://doi.org/10.1080/10454446.2019.1679690.

Kardes, F.R., Cronley, M.L., and Cline, T.W. (2011). Consumer Behavior. Cengage Learning.

Kim, H.W., Xu, Y., and Gupta, S. (2012). Which is more important in Internet shopping, perceived price or trust? Electronic Commerce Research and Applications, 11(3), 241-252. https://doi.org/10.1016/j.elerap.2011.06.003.

Kock, N., and Lynn, G.S. (2012). Lateral collinearity and misleading results in variance-based SEM: An illustration and recommendations. Journal of the Association for Information Systems, 13(7), 546-580. https://doi.org/10.17705/1jais.00302.

Lee, J., and Lee, Y. (2018). Effects of multi-brand company's CSR activities on purchase intention through a mediating role of corporate image and brand image. Journal of Fashion Marketing and Management, 22(3), 387-403. https://doi.org/10.1108/JFMM-08-2017-0087.

Li, Y., Teng, W., Liao, T.T., and Lin, T.M.Y. (2020). Exploration of patriotic brand image: its antecedents and impacts on purchase intentions. Asia Pacific Journal of Marketing and Logistics. https://doi.org/10.1108/APJML-11-2019-0660. 
Liang, A.R. Da, and Lim, W.M. (2020). Why do consumers buy organic food? Results from an S-O-R model. Asia Pacific Journal of Marketing and Logistics.

https://doi.org/10.1108/APJML-03-2019-0171.

Lien, C.H., Wen, M.J., Huang, L.C., and Wu, K.L. (2015). Online hotel booking: The effects of brand image, price, trust and value on purchase intentions. Asia Pacific Management Review, 20(4), 210-218. https://doi.org/10.1016/j.apmrv.2015.03.005.

Liu, C., Bao, Z., and Zheng, C. (2019). Exploring consumers' purchase intention in social commerce: An empirical study based on trust, argument quality, and social presence. Asia Pacific Journal of Marketing and Logistics, 31(2), 378-397. https://doi.org/10.1108/APJML-05-2018-0170.

Liu, H., Chu, H., Huang, Q., and Chen, X. (2016). Enhancing the flow experience of consumers in China through interpersonal interaction in social commerce. Computers in Human Behavior, 58, 306-314. https://doi.org/10.1016/j.chb.2016.01.012.

McKinsey \& Company (2018). Middle Eastern Sentiment Survey. https://www.mckinsey.com/ /media/ McKinsey/Locations/Europe and Middle East/Middle East/Our insights/ME-Consumer-Survey-2018.

Mehrabian, A., and Russell, J.A. (1974). An Approach to Environmental Psychology. The MIT Press.

Memon, M.A., Salleh, R., Mirza, M.Z., Cheah, J.H., Ting, H., Ahmad, M.S., and Tariq, A. (2020). Satisfaction matters: the relationships between HRM practices, work engagement and turnover intention. International Journal of Manpower. https://doi.org/10.1108/IJM-04-2018-0127.

Muskat, B., Hörtnagl, T., Prayag, G., and Wagner, S. (2019). Perceived quality, authenticity, and price in tourists' dining experiences: Testing competing models of satisfaction and behavioral intentions. Journal of Vacation Marketing, 25(4), 480-498. https://doi.org/10.1177/1356766718822675.

Nielsen (2017). "Made in" matters... or does it? Obtained from: https://www.nielsen.com/wp-content/ uploads/sites/3/2019/04/global-vs-local-brands-report-1.pdf.

Nisar, Q.A., Haider, S., Ali, F., Naz, S., and Ryu, K. (2021). Depletion of psychological, financial, and social resources in the hospitality sector during the pandemic. International Journal of Hospitality Management, 93, 102794. https://doi.org/10.1016/j.ijhm.2020.102794.

OECD and FAO (2018). OECD-FAO Agricultural Outlook 2018-2027.

Prince, M. (2020). Domestic Product Involvement and Consumer Willingness to Buy Domestic Products: Empirical Testing of a Cognitive Consistency Theory Framework. Journal of International Consumer Marketing, 32(5), 453-461. https://doi.org/10.1080/08961530.2020.1727393.

Rajaguru, R. (2016). Role of value for money and service quality on behavioural intention: A study of full service and low cost airlines. Journal of Air Transport Management, 53, 114-122. https://doi.org/10.1016/j.jairtraman.2016.02.008.

Ramayah, T., Cheah, J., Chuah, F., Ting, H., and Memon, M.A. (2018). Partial Least Squares Structural Equation Modeling (PLS-SEM) using SmartPLS 3.0: An Updated Guide and Practical Guide to Statistical Analysis (2nd ed.). Pearson.

Samudro, A., Sumarwan, U., Simanjuntak, M., and Yusuf, E.Z. (2020). Assessing the effects of perceived quality and perceived value on customer satisfaction. Management Science Letters, 10(5), 1077-1084. https://doi.org/10.5267/j.msl.2019.11.001

Sarstedt, M., Hair, J. F., Nitzl, C., Ringle, C.M., and Howard, M.C. (2020). Beyond a tandem analysis of SEM and PROCESS: Use of PLS-SEM for mediation analyses! International Journal of Market Research, 62(3), 288-299. https://doi.org/10.1177/1470785320915686.

Setiawan, E.B., Kartini, D., Afiff, F., and Rufaidah, P. (2016). Impact of Price Fairness on Brand Image and Purcase Intention for Low Cost Car in Indonesia. International Journal of Economics, Commerce and Management, IV(9), 300-308. 
Sharma, P. (2011). Country of origin effects in developed and emerging markets: Exploring the contrasting roles of materialism and value consciousness. Journal of International Business Studies, 42(2), 285-306. https://doi.org/10.1057/jibs.2010.16.

Shi, B., Zhang, D., Xie, H., and Zhou, Y. (2016). Antecedents of Chinese adolescents' purchase intention for local brands: the moderating influence of materialistic values. Journal of Consumer Marketing, 33(4), 292-301. https://doi.org/10.1108/JCM-07-2014-1045.

Souiden, N., Ladhari, R., and Chang, L. (2018). Chinese perception and willingness to buy Taiwanese brands: The role of ethnocentrism and animosity. Asia Pacific Journal of Marketing and Logistics, 30(4), 816-836. https://doi.org/10.1108/APJML-09-2017-0203.

Su, D.N., Nguyen-Phuoc, D.Q., and Johnson, L.W. (2019). Effects of perceived safety, involvement and perceived service quality on loyalty intention among ride-sourcing passengers. Transportation. https://doi.org/10.1007/s11116-019-10058-y.

Sumaedi, S., Bakti, I., and Metasari, N. (2011). The Effect of Students' Perceived Service Quality and Perceived Price on Student Satisfaction. Management Science and Engineering, 5(1), 88-97. https://doi.org/10.3968/j.mse.1913035X20110501.010.

Suparno, C. (2020). Online purchase intention of halal cosmetics: SOR framework application. Journal of Islamic Marketing. https://doi.org/10.1108/JIMA-09-2019-0192.

Tenenhaus, M., Vinzi, V.E., Chatelin, Y.M., and Lauro, C. (2005). PLS path modeling. Computational Statistics and Data Analysis, 48(1), 159-205. https://doi.org/10.1016/j.csda.2004.03.005.

Watanabe, E.A. de M., Torres, C.V., and Alfinito, S. (2019). The impact of culture, evaluation of store image and satisfaction on purchase intention at supermarkets. Revista de Gestão, 26(3), 256-273. https://doi.org/10.1108/rege-12-2017-0009.

Winit, W., Gregory, G., Cleveland, M., and Verlegh, P. (2014). Global vs local brands: How home country bias and price differences impact brand evaluations. International Marketing Review, 31(2), 102-128. https://doi.org/10.1108/IMR-01-2012-0001.

Xiao, L., Guo, F., Yu, F., and Liu, S. (2019). The effects of online shopping context cues on consumers' purchase intention for cross-border E-Commerce sustainability. Sustainability, 11(10), 1-24. https://doi.org/10.3390/su11102777.

Yen, Y.S. (2018). Extending consumer ethnocentrism theory: the moderating effect test. Asia Pacific Journal of Marketing and Logistics, 30(4), 907-926. https://doi.org/10.1108/APJML-09-2017-0226.

Zeithaml, V.A. (1988). Consumer Perceptions of Price, Quality, and Value: A Means-End Model and Synthesis of Evidence. Journal of Marketing, 52(3), 2-22. https://doi.org/10.1177/002224298805200302. 


\section{Appendix}

Appendix A1. Measurements and sources

\section{Measurement Items}

Sources

\section{Perceived Quality (PQ)}

$P Q 1$ : It is elegant to use local dairy products.

$P Q 2:$ It is attractive to use local dairy products.

PQ3: Local dairy products are of good quality.

PQ4: The material used in local dairy products is of good quality.

PQ5: Local dairy products are flawless.

PQ6: Local dairy products are durable.

$P Q 7$ : Local dairy products are reliable.

\section{Perceived Price (PP)}

(Yen, 2018)

PP1: The price of local dairy products is considerable money to spend.

PP2: The price of local dairy products is much more than I expected.

PP3: In general, I find using local dairy products would cost me considerably money.

\section{Customer Satisfaction (SAT)}

SAT1: I feel satisfied with local dairy products.

SAT2: I feel delighted with my experience with the local dairy products.

SAT3: The local dairy products meet my expectations.

SAT4: I would buy the local dairy product on the next opportunity.

SAT5: I would recommend the local dairy product to others.

\section{Brand Image (BRI)}

(Lien et al., 2015)

BRI1: The brand of local dairy products is reliable.

BRI2: The brand of local dairy products is attractive.

BRI3: The brand of local dairy products is pleasing.

BRI4: The brand of local dairy products is a social status symbol.

BRI5: The brand of local dairy products has a good reputation.

\section{Purchase Intention (PUI)}

(Yen, 2018)

PUI1: The likelihood that I would pay for local dairy products is high.

PUI2: My willingness to buy local dairy products is very high.

PUI3: In the near future, I would consider purchasing local dairy products.

Source: own elaboration of the literature.

(Yen, 2018)

\author{
(Aaker, 1991;
Dai et al., 2015) \\ (Aaker, 1991;
Dai et al., 2015)
}

